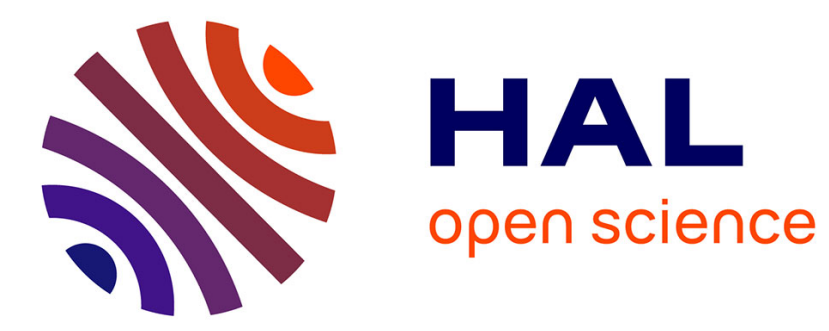

\title{
Control of bone and fat mass by oxytocin
}

Ez-Zoubir Amri, Didier Pisani

\section{- To cite this version:}

Ez-Zoubir Amri, Didier Pisani. Control of bone and fat mass by oxytocin. Hormone Molecular Biology and Clinical Investigation, 2016, 28 (2), pp.95-104. 10.1515/hmbci-2016-0045 . hal-02134850

\section{HAL Id: hal-02134850 \\ https://hal.science/hal-02134850}

Submitted on 9 Dec 2021

HAL is a multi-disciplinary open access archive for the deposit and dissemination of scientific research documents, whether they are published or not. The documents may come from teaching and research institutions in France or abroad, or from public or private research centers.
L'archive ouverte pluridisciplinaire HAL, est destinée au dépôt et à la diffusion de documents scientifiques de niveau recherche, publiés ou non, émanant des établissements d'enseignement et de recherche français ou étrangers, des laboratoires publics ou privés. 


\section{Ez-Zoubir Amri* and Didier F. Pisani \\ Control of bone and fat mass by oxytocin}

DOI 10.1515/hmbci-2016-0045

Received October 3, 2016; accepted October 18, 2016

\begin{abstract}
Osteoporosis and overweight/obesity constitute major worldwide public health burdens. Aging is associated with a decrease in hormonal secretion, lean mass and bone mass, and an increase in fat accumulation. It is established that both obesity and osteoporosis are affected by genetic and environmental factors, bone remodeling and adiposity are both regulated through the hypothalamus and sympathetic nervous system. Oxytocin (OT), belongs to the pituitary hormone family and regulates the function of peripheral target organs, its circulating levels decreased with age. Nowadays, it is well established that OT plays an important role in the control of bone and fat mass and their metabolism. Of note, OT and oxytocin receptor knock out mice develop bone defects and late-onset obesity. Thus OT emerges as a promising molecule in the treatment of osteoporosis and obesity as well as associated metabolic disorders such as type 2 diabetes and cardiovascular diseases. In this review, we will discuss findings regarding the OT effects on bone and fat mass.
\end{abstract}

Keywords: adipocyte; obesity; osteoblast; osteoporosis; oxytocin.

\section{Introduction}

Human life expectancy is continuously increasing in industrialized countries. Aging is associated with immunosenescence, decrease in hormonal secretion, metabolism, lean mass and bone mass, and increase in fat accumulation. Among disorders commonly considered as being age-related, which represent a major cause of morbidity and mortality, are osteoarthritis, osteoporosis, obesity, atherosclerosis and neurodegenerative diseases. Osteoporosis and overweight/obesity constitute major worldwide public health burdens. It is well established that tight links

\footnotetext{
*Corresponding author: Dr. Ez-Zoubir Amri, iBV, Université de Nice Sophia-Antipolis, UMR7277 CNRS - UMR1091 INSERM, Faculté de Médecine, 28 Avenue de Valombrose 06107 Nice cedex 2, France, Phone: +33 4933777 82, E-mail: amri@unice.fr; and Université Côte d'Azur, CNRS, Inserm, iBV, France

Didier F. Pisani: Université Côte d’Azur, CNRS, Inserm, iBV, Nice, France
}

between osteoporosis and adiposity exist. An inverse relationship between osteogenesis and adipogenesis is well documented and thus controlling the fine balance between these two pathways is of clear therapeutic significance [1]. During the last decade, the role of a hypothalamic nonapeptide, the oxytocin (OT), has been described in the control of bone remodeling and adiposity [2-5] and thus represent an interesting strategy to treat bone and fat related disorders. Herein, we will describe the role of OT and its involvement in bone and adipose tissue homeostasis.

\section{Oxytocin and its receptor}

\section{Generalities}

OT was discovered in 1906 [6] when Sir Henry H. Dale found that an extract from the human posterior pituitary gland contracted the uterus of a pregnant cat. OT belongs to the family of pituitary hormones and is considered as an abundant neuropeptide displaying homologs all along evolution (for review see [7]). The structure of OT was determined and was the first chemically synthesized peptide in a biologically active form [8]. Like all neurohypophysial hormones, OT is a nonapeptide with a disulfide bridge between Cys residues 1 and 6. OT displays a wide spectrum of central and peripheral functions (Figure 1), from the modulation of neuroendocrine reflexes arcs including hormone secretion, to the establishment of social and relationship behaviors $[9,10]$. OT is also known as the "love hormone" due to its involvement in attachments, reproduction behaviors, offspring care, as well as its ethnical connections $[11,12]$.

OT has long been considered to be restricted to the stimulation of uterine contractions and milk ejection. Due to this, OT is commonly used in medical obstetrics to facilitate labor in all vertebrates without significant side effects [13]. The fact that OT is found in equivalent concentrations in the neurohypophysis and plasma of both sexes suggests that OT has other physiological functions. OT is predominantly synthesized within the magnocellular neurons of the hypothalamus, but also in some peripheral tissues, including the reproductive system, heart, and bone $[9,14,15]$, and its secretion is modulated by various factors, including estrogens, testosterone and leptin $[9,16,17]$. 
The OT receptor (OTR) is a 389-amino acid polypeptide with seven transmembrane domains first isolated and identified in humans [18]. The OTR gene is expressed in a variety of peripheral tissues and its expression is regulated by various signals, e.g. by steroids in the uterus or hypothalamus [9]. OTR belongs to the class I G proteincoupled receptor (GPCR) family and is functionally coupled to the Goq class GTP binding proteins that stimulate the activity of phospholipase $C$ [9]. This activity leads to the generation of inositol trisphosphate which triggers $\mathrm{Ca}^{2+}$ release from intracellular stores, and of diacylglycerol which stimulates protein kinase $C$. These well-known pathways initiate a variety of cellular events. For example, in myometrial or mammary myoepithelial cells, they trigger the activation of myosin light-chain kinase activity which initiates smooth muscle contraction [19]. Due to the closely related sequences of OT and vasopressin, these pituitary hormones can act directly on each other's receptor, respectively, OTR and arginine vasopressin receptor 1A (AVPRIA) [20]. Sometimes this activation allows the induction of functions in an opposite manner [21].

Finally, OT function can be mediated through OT production, as well as by modulation of OTR expression. Its actions are related to sexual physiological responses and behavior, but can be distinguished between central and peripheral effects.

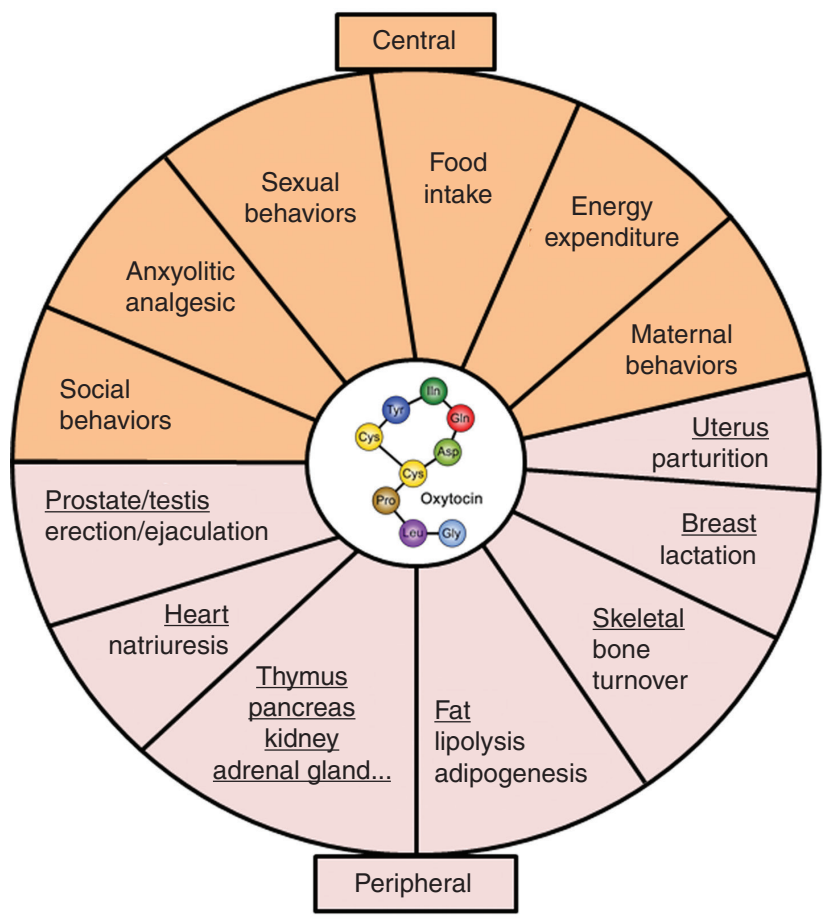

Figure 1: Central and peripheral effects of oxytocin.

\section{OT central action}

In the central nervous system, OT is mainly expressed in magnocellular neurons within hypothalamic regions. Activation of these neurosecretory cells triggers the release of OT in the neurohypophysis [22]. The essential function of OT takes place in this brain area, as for example, it has an important role in milk ejection in response to suckling [23]. OT can be released also in the adenohypophysis and may participate in the physiological regulation of the adenohypophysial hormones such as ACTH [24]. In human, OT infusion inhibited the plasma ACTH in response to corticotropin-releasing hormone (CRH), found, for example, in the case of suckling and breast stimulation [25]. Thus, OT might control corticotropic activity of the adrenal gland via the inhibition of ACTH release under some physiological conditions.

Another central function of OT, depending on its positive behavior action, is its analgesic activity. Indeed, OT is able to increase $\beta$-endorphin and L-encephalin release, and OT antagonists decrease the concentration of these opioids. Moreover, intrathecal injection of OT is effective in treating low back pain in humans, an effect reversed by the opiate receptor-blocker naloxone [26]. This interaction between OT and the opioid system is also involved in sexual behaviors [27].

Several studies have shown that OT action in the hypothalamus facilitates both aspects of sexual behavior (perceptive and receptive), certainly in association with other sexual hormones [28]. This is true in a large number of species, but in humans the OT role seems more related to its anxiolytic properties facilitating social interactions [29]. This anxiolytic property of OT is important in human and animal studies as stress can induce release of OT in the brain and plasma, and thus might mask the real experimental level and action of OT.

OT, the "love hormone", exhibits a positive effect in sexual and non-sexual social behaviors [30]. This is highlighted by two interesting studies demonstrating the effect of OT on social trust and favoritism within a group [31,32].

\section{OT peripheral action}

The uterus represents the main and classical tissue target of OT during pregnancy. During the late stages of labor, the uterine sensitivity to OT is due to an increased expression of OTR especially in the myometrium, which decreases after parturition. In rats, OT mRNA increased at term, indicating an autonomous OT pathway in the uterus, however, this observation remains to be proven 
in other species including humans [9]. Nevertheless, due to this uterotonic capacity, OT is clinically used to induce labor in all mammals. However, OT has been detected in various cells of the ovary and corpus luteum, and thus may participate in early development and/or fertilization [33]. One of the other classical roles assigned to OT is milk ejection from the mammary gland. The secretion of the mammary glands is triggered by the stimulation of tactile receptors on the nipple when the infant begins to suck. This generates a signal to the secretory oxytocinergic neurons in the hypothalamus which leads to massive release of OT into the bloodstream and thus reaches the lactating breasts [9].

In males, particularly in humans, OT production and OTR are present in the testis, epididymis and prostate [34]. In addition to hypothalamic OT production, OT peripheral tissue production, might be involved in the contraction of the prostate, in the expulsion of prostatic secretions and finally in ejaculation [35].

OT is also involved in the control of blood volume and osmolality. OT is described as a natriuretic agent in the rat but its contribution to renal physiology in primates including humans has not yet been described [36]. Additionally, injection of OT decreases mean arterial pressure and leads to the stimulation of atrial natriuretic peptide (ANP) release [37]. The ANP released would also act on the kidneys to induce natriuresis, and within the brain to inhibit water and salt intake. These events lead to a gradual recovery of circulating blood volume to normal.

OT has been detected in other peripheral tissues including in the thymus, pancreas and adrenal gland, with different proposed potential function, demonstrating the wide spectrum of action of this hormone. Finally, OT is produced by osteoblasts [38] and adipocytes and acts on bone and fat tissues, its function on these issues will be presented in this review.

\section{Fat and bone crosstalk}

Several observations link obesity with osteoporosis: i) both diseases are affected by genetic and environmental factors, or the interaction between them, ii) normal aging is associated with both a high incidence of osteoporosis and bone marrow adiposity [39], iii) bone remodeling and adiposity are both regulated through the hypothalamus and sympathetic nervous system, iv) adipocytes and osteoblasts derive from a common progenitor, the mesenchymal stem cell [40-43], v) adipose tissue is an endocrine organ [44], and the skeleton has emerged also as an endocrine organ, vi) pathophysiological relevance of adipose tissue in bone integrity resides in the participation of adipokines in bone remodeling, while the skeleton has effects on body weight control and glucose homeostasis through the actions of bone-derived factors such as osteocalcin and osteopontin [45-47]. Thus, there is an active cross-talk between adipose tissue and the skeleton constituting a homeostatic feedback system with adipokines and molecules secreted by osteoblasts and osteoclasts.

Osteoporosis is defined by the deterioration of bone density and microarchitecture leading to bone fragility [48]. The strength and integrity of the bone depend on the balance between resorption by osteoclasts and bone formation by osteoblasts $[49,50]$. The decrease of bone mass which occurs during osteoporosis implies an acceleration of the "bone turn-over" with an imbalance between resorption and formation in favor of bone resorption [51, 52]. In addition, osteoporosis is associated with a gain in bone marrow adiposity, due to the formation of adipocytes from mesenchymal stem cells (MSC) at the expense of osteoblasts, and this adiposity is also connected to the prevalence of bone fracture in osteoporosis [43].

Associated with these bone features, post-menopausal women display body weight gain which preferentially affects the visceral (or intra-abdominal) fat depot associated with a transition of body distribution from a gynoid to an android type [53-55]. This shift in fat mass distribution favors the development of insulin resistance, which leads finally to pancreatic abnormalities, and is associated to a change in the secretion of various adipokines involved in bone turn-over. It is demonstrated that a negative correlation exits between bone and body fat mass, suggesting that obesity represents a risk for osteoporosis [40, 56, 57]. Moreover, visceral adipose tissue increase seems detrimental for bone mineral density in premenopausal obese women [58-61]. It is accepted that hypogonadism also induces adiposity in males, but the specific relation with visceral adiposity is less important $[62,63]$. Finally, hormonal disturbance found in men and women can be considered at the onset of osteoporosis, adipose tissue is linked to the development of this pathology as it is a secretory organ [39].

On the one hand, evidence has shown that osteoblasts act in an endocrine fashion by the production and secretion of factors which are able to alter distant tissue function [64]. Osteocalcin, is an interesting endocrine factor produced by osteoblasts, as it seems to play an important role in energy metabolism. Mice lacking osteocalcin in the osteoblast lineage display decreased pancreatic $\beta$-cell proliferation and insulin secretion and increased adiposity. Moreover, uncarboxylated osteocalcin is able to 
stimulate production of adiponectin by adipocytes, which favors insulin sensitivity $[47,65]$.

On the other hand, adipose tissue is known to exert endocrine function with secretion of adipokines and steroids, both of which are involved in bone homeostasis. Adipocytes from bone marrow secrete adipokines which can act in a paracrine manner. Leptin, a well-known adipokine, has been extensively studied in relation to bone. Leptin regulates osteoclast development and the production of osteoclast and osteoblast growth factors [66]. Thus its combined effects on bone formation and resorption defined leptin as a major participant in bone development, and alteration in its plasmatic and marrow level may affect bone homeostasis. Adiponectin increases osteoblasts differentiation and inhibits osteoclastogenesis and osteoclast activity, leading to an increased bone mass in mice [67]. The fact that adiponectin circulating levels are reduced in obesity can link fat mass increase to bone loss in this situation.

Other tissues, peripheral or central, can act as intermediate between bone and fat, and especially the pancreas which is modulated by adipokines and secretes endocrine factors, i.e. preptin and amylin, known to modulate bone turn-over (for review see [68]).

Altogether these observations demonstrated the existence of an active crosstalk between i) adipocyte and osteoblast, and ii) adipose tissue and the skeleton and constitutes a homeostatic feedback system with adipokines and bone derived molecules, controlling the fine balance between the two pathways is of clear therapeutic significance $[1,45,69]$. In the search for pathways regulating this crosstalk, OT was discovered as a major contributor $[4,5,15,70]$. Indeed, OT promotes the formation of osteoblasts in vitro at the expense of adipocytes, as well as preventing and reversing osteoporotic and obese phenotype in vivo.

\section{OT regulates osteoblast/adipocyte balance}

It has been shown that OT $\left(\mathrm{OT}^{-/-}\right)$and OTR $\left(\mathrm{OTR}^{-/-}\right)$knockout mice develop osteoporosis $[3,5,15]$. The observed defect in bone formation, associated with a decrease in osteoblast differentiation could be normalized by an intra-peritoneal injection of OT [5]. It is worth noting that haploinsufficient OT or OTR mice $\left(\mathrm{OT}^{+/}\right.$, $\mathrm{OTR}^{+/-}$) develop osteopenia whereas milk let-down remains normal [5]. Furthermore, $\mathrm{OT}^{-1-}$ mice become obese without hyperphagia and present a low sympathetic tone [71, 72].

\section{In vitro studies}

OTR is expressed by various cells including adipocytes, osteoblasts and osteoclasts. It has been shown that OT is able to induce the proliferation of human osteoblast-like cells [73] and inhibit the adipogenesis of the preadipocyte cell line 3T3-F442A [74]. Indeed, as osteoblasts and adipocytes share the same progenitor, i.e. MSC isolated from different tissues, analysis of the early step of commitment to either lineage has demonstrated that OTR expression was differentially expressed with high levels in osteoblasts [75]. Moreover, treatment of adipose-derived MSCs during differentiation with OT or a stable analog, carbetocin, enhanced osteogenesis at the expense of adipogenesis [4]. Interestingly, in the presence of a combined adipogenic/osteogenic medium, cells within a single culture dish differentiated into the two cell types. Their proportion was then altered in the expected way (adipogenesis down and osteogenesis up) when cells were chronically treated by OT or carbetocin, demonstrating a direct role of this hormone in the adipocyte/osteoblast balance [4]. Bone marrow-derived MSCs exhibit similar observations in agreement with the invasion of bone marrow by adipocytes at menopause.

The mechanisms involved in the OT pathway and governing this balance are not known yet. Nevertheless, studies on adipocyte or osteoblast showed that OT is able to induce an intracellular $\mathrm{Ca}^{2+}$ rise in these two type of cells. Indeed, OTR activation in osteoblast triggers increased intracellular $\mathrm{Ca}^{2+}$ concentration [76]. Furthermore, it is well known that OT is involved in PIP2 breakdown in adipocyte, allowing the activation of $\mathrm{Ca}^{2+}$-dependent pathway $[77,78]$. This increased intracellular $\mathrm{Ca}^{2+}$ levels induces a transient phosphorylation of ERK1/2, reported also in committed mesenchymal progenitors treated with OT [4]. These data are consistent with observations showing that activation of the $\mathrm{Ca}^{2+}$-ERK1/2 pathway leads, on the one hand, to phosphorylation of core-binding factor subunit alpha-1 (CBFA1), the osteoblast differentiation key transcription factor also known as runt-related transcription factor 2 (RUNX2), which enhances osteogenesis [79], and on the other hand, to phosphorylation of peroxisome proliferator-activated receptor $\gamma(P P A R \gamma)$, the adipocyte differentiation master gene, which inhibits its adipogenic activity (Figure 2) [80, 81].

Recently an original alternative pathway has been described that might explain the OT action in osteogenesis [82]. As described for some other GPCRs, OTR can be internalized after activation by OT and translocated to the nucleus. This internalization is dependent on the $\beta$-arrestin1 pathway without affecting the ERK1/2 pathway. 


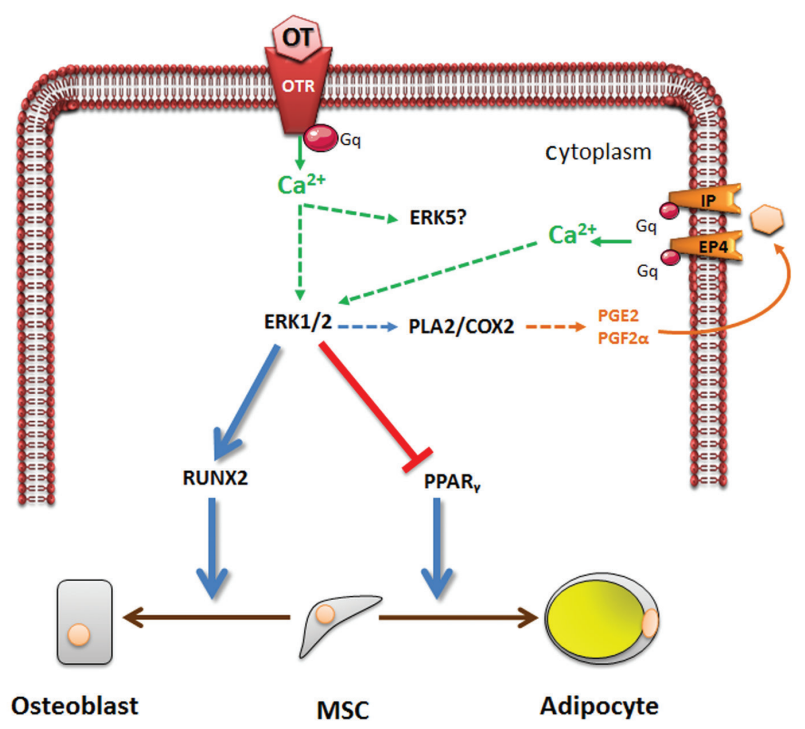

Figure 2: OT signaling in adipocyte/osteoblast balance. MSC, Mesenchymal stem cell.

The involvement of this pathway in the adipocyte/osteoblast balance is not yet elucidated and further analyses are required. Of note, $\beta$-arrestin1 is a negative modulator of adipogenesis through its direct interaction with PPAR $\gamma$ [83] suggesting a critical role of $\beta$-arrestin1 in the adipocyte/osteoblast balance.

\section{In vivo studies}

Transcription of OT and its receptor are up-regulated by estrogens. Menopause is accompanied by decreased estrogen production and often associated with osteoporosis and very often increased fat mass. Menopause is one of the critical periods of a woman's life during which body weight gain and onset or worsening of obesity are favored [84-87]. It is at this period of hypo-estrogenism that obesity prevalence is at its highest whereas aging favors also have a positive energy balance. This body weight gain is related to adverse health effects that worsen due to changes in fat distribution observed during menopause, i.e. increased visceral adiposity [55]. This increase favors the development of insulin resistance and its clinical outcomes such as carbohydrate metabolism impairments and type 2 diabetes, hypertension and dyslipidemia, leading to increased cardiovascular risks, and cancer among other diseases [88]. The use of estrogens has been shown to normalize visceral fat mass in both animals and humans [85, 89-91]. However, the diverse effects of estrogens on non-fat organs hamper the possibility of using this hormone therapeutically as many controversial studies have been reported, in which hormonal substitutive therapy may lead to cardiovascular diseases and breast cancer [92-95]. Whereas most of osteoporosis treatments target bone resorption by inhibiting osteoclast formation and activity, only a few promote bone formation [96-98]. Therapies developed to treat bone diseases in humans are considered to be either anti-resorptive (including estrogen, bisphosphonates, selective estrogen-receptor modulators, calcitonin, vitamin D), anabolic (parathyroid hormone) or both (strontium renelate) [51, 99, 100]. For most of these treatments, if not all, side-effects have been reported, i.e. osteonecrosis of the jaw, atypical fractures of the femur, dysphagia, esophagitis, headache, nausea, arthralgy and dizziness among others [101-103]. Identification of such drugs would enable the development of alternative and/ or complementary treatments. As mentioned above, in addition to bone loss, osteoporosis is associated with an increased bone marrow adiposity leading to the formation of adipocytes at the expense of osteoblasts leading bone to be prone to fractures [104].

Besides exercise and food restriction, there is no efficient treatment to prevent body weight gain and fat mass redistribution at the onset of menopause, whereas substitutive hormonal treatment may lead to side effects on a long-term basis, hence the need for more targeted therapies. The normalization of body weight gain and the prevention of redistribution of body fat during menopause is a major health issue that would prevent the appearance of various symptoms of the metabolic syndrome. As estrogen levels are decreased in ovariectomized (OVX) mice or rats (a situation mimicking the transition to menopause in women) and in postmenopausal women, OT levels were expected to be decreased in both cases. Indeed, plasma OT levels were lower in OVX mice and rats compared to sham-operated controls [4]. Daily subcutaneous OT injection for 8 weeks reversed bone loss in OVX mice by improving bone microarchitecture and biomechanical strength and reduced bone marrow adiposity. This effect of OT was effective in a preventive as well as in a curative manner [2]. Interestingly, body weight gain, fat mass redistribution and bone marrow adiposity were normalized upon OT treatment of OVX mice [2].

The action of OT on bone mass is primarily associated with normalization of the osteoblast/osteoclast ratio due to an increased differentiation of osteoblast and modulation of osteoclast formation and function $[2,5]$. In addition to a decrease in bone marrow adiposity due to its effect on adipocyte/osteoblast balance, OT induced body weight loss and reduction of visceral adipose tissue mass in OVX mice which could be due to changes in metabolic 
pathways. Analysis of different parameters of energy balance showed that OT treatment induced a switch favoring a preferential use of lipids rather than carbohydrates [2]. Promoting the utilization of fatty acids within the fat cells is a way to limit their release into the bloodstream and thereby to alleviate their systemic side effects. Furthermore, it has recently been shown that a novel pathway by which cardiac natriuretic peptides, through its receptor NPRA, cGMP and PKG can activate p38 $\alpha$ MAPK to increase mitochondrial biogenesis and uncoupled respiration [105]. Importantly, it has been shown that ANP and $\beta$-adrenergic agonists can act together in an additive manner to more robustly promote brown adipocyte features and functions. These observations might support the concept of cardiac natriuretic peptides as cardiometabolic hormones that are able to turn on the machinery characteristic of brown fat thermogenesis in human and mouse adipocytes. Thus cardiac natriuretic peptides together with catecholamine may modulate energy expenditure to regulate the distribution of body fat and lean mass with a relevant role in controlling cardiovascular risk and potentially inducing beneficial metabolic effects in the cardiometabolic patients [105]. Of note, perfusion of female rat hearts with OT resulted in a significantly stimulated ANP release [37]. As chronic BNP perfusion in mice has an enhancing effect on oxygen consumption and the expression of brown adipocyte markers in adipose tissue, it is tempting to postulate that ANP might be involved in the effects of OT. Thus, the hypothesis that OT treatment, through ANP secretion, participate to an increased lipolysis or in the conversion of mature white adipocytes into fat-burning cells cannot be excluded.

Anti-obesity effects of OT given either centrally or peripherally have been reported using diet induced obese rats. Indeed, high fat diet induced obese rats that received OT loose body weight and fat mass through the activation of PPAR $\alpha$ pathway, increased lipid utilization and decreased food intake $[70,106,107]$. OT treatment, intraperitoneal injection, induced a decreased food intake and body weight in diet induced obese rats [108]. Interestingly, OT beneficial effects on body weight reduction can be observed in mice and rat but also in other animal models such as rabbits as OT treatment was sufficient to eliminate glucocorticoid-induced marrow adiposity [109].

In orchidectomized mice (animal model of hypogonadism in male) OT treatment normalized fat mass and its redistribution as it did in female mice; however, OT treatment did not normalize bone defects. Altogether, these observations indicate that OT affects bone physiology only in females and fat physiology in both genders [110].

\section{OT circulating levels}

Several reports analyzed circulating levels of OT, it appears that the levels are not in agreement with OTR affinity and that an extraction step is mandatory before measurements [111]. Circulating levels of OT are reported to be associated with the development of bone and fat mass defects.

Indeed, OT plasma levels were correlated with the development of osteopenia or osteoporosis in a small and confirmed in a large postmenopausal women cohort $[4,112,113]$ where higher OT levels were associated with higher bone mineral density. These data are in agreement with previous observations reported in mice and rats [4]. It has been suggested that the decreased OT levels associated with overweight and obesity can be associated with an increased rate of OT degradation due to oxytocinase activity [114].

However, for men, in agreement with the lack of effects of OT on osteoporotic male mice, OT levels were not linked to bone mineral density, bone turnover rate, or prevalent fractures [115].

\section{Conclusion}

It is now well established that OT plays an important role in the control of energy metabolism [116]. Moreover, reports are in favor of a crucial role of OT in humans as OT treatments allow a decreased food intake and lower OT levels in obese and diabetic patients [117-120]. Given the relationship between adipocyte and osteoblast, OT is clearly controlling the fine balance between these two types of cells. Collectively, these observations indicate that OT plasma levels represent a novel diagnostic marker for bone and fat related disease and that OT administration holds promise as a potential therapy to combat

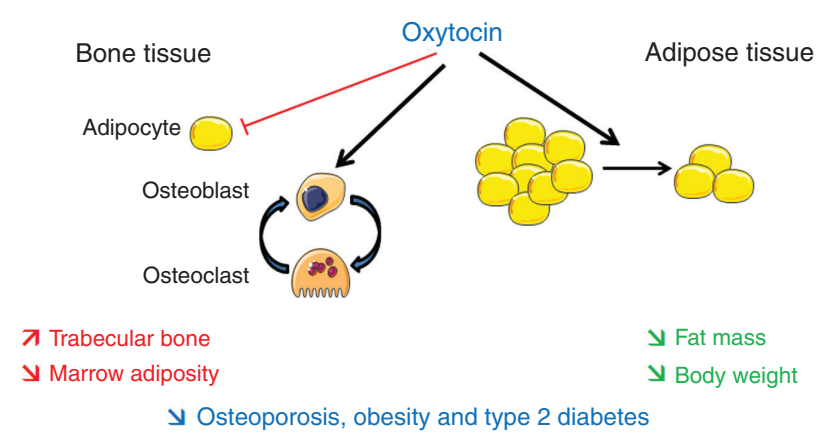

Figure 3: Schematic representation of the effects of OT on adipose and bone tissues leading to reduction of osteoporosis, obesity and associated metabolic disorders. 
osteoporosis, overweight, obesity and associated diseases such as diabetes and cardiovascular disorders (Figure 3). Further studies, including large human cohorts, are required and will shed some light on the clinical efficiency of OT. As it is well known that OT half-life is very short, characterization of stable OT analogs, harboring extended half-life, such as carbetocin [121] or conjugated OT [122] is of high importance for an efficient treatment. Alternatively, it is well established that oxytocinases are very active; an approach consisting in the development of oxytocinase inhibitors represents a potential therapeutic option.

Acknowledgments: This work was supported by CNRS, Inserm, University Côte d'Azur, Fondation pour la Recherche Médicale (grant DVO20081013470) and the Conseil Général des Alpes Maritimes (CG06).

\section{Author Statement}

Funding: Authors state no funding involved.

Conflict of interest: Authors state no conflict of interest. Informed consent: Informed consent has been obtained from all individuals included in this study.

Ethical approval: The research related to human use complies with all the relevant national regulations, institutional policies and was performed in accordance to the tenets of the Helsinki Declaration, and has been approved by the authors' institutional review board or equivalent committee.

\section{References}

1. Nuttall ME, Gimble JM. Controlling the balance between osteoblastogenesis and adipogenesis and the consequent therapeutic implications. Curr Opin Pharmacol 2004;4:290-4.

2. Beranger GE, Pisani DF, Castel J, Djedaini M, Battaglia S, Amiaud J, Boukhechba F, Ailhaud G, Michiels JF, Heymann D, Luquet S, Amri EZ. Oxytocin reverses ovariectomy-induced osteopenia and body fat gain. Endocrinology 2014;155:1340-52.

3. Colaianni G, Sun L, Zaidi M, Zallone A. The "love hormone" oxytocin regulates the loss and gain of the fat-bone relationship. Front Endocrinol (Lausanne) 2015;6:79.

4. Elabd C, Basillais A, Beaupied H, Breuil V, Wagner N, Scheideler M, Zaragosi LE, Massiera F, Lemichez E, Trajanoski Z, Carle G, Euller-Ziegler L, Ailhaud G, Benhamou CL, Dani C, Amri EZ. Oxytocin controls differentiation of human mesenchymal stem cells and reverses osteoporosis. Stem Cells 2008;26:2399-407.

5. Tamma R, Colaianni G, Zhu LL, DiBenedetto A, Greco G, Montemurro G, Patano N, Strippoli M, Vergari R, Mancini L, Colucci S, Grano M, Faccio R, Liu X, Li J, Usmani S, Bachar M, Bab I, Nishimori K, Young LJ, Buettner C, Iqbal J, Sun L, Zaidi M, Zallone A. Oxytocin is an anabolic bone hormone. Proc Natl Acad Sci USA 2009;106:7149-54.
6. Dale HH. On some physiological actions of ergot. J Physiol 1906;34:163-206.

7. Banerjee P, Joy KP, Chaube R. Structural and functional diversity of nonapeptide hormones from an evolutionary perspective: a review. Gen Comp Endocrinol 2016. Doi: 10.1016/j.ygcen.2016.04.025.

8. Du Vigneaud V, Ressler C, Trippett S. The sequence of amino acids in oxytocin, with a proposal for the structure of oxytocin. J Biol Chem 1953;205:949-57.

9. Gimpl G, Fahrenholz F. The oxytocin receptor system: structure, function, and regulation. Physiol Rev 2001;81:629-83.

10. Lee HJ, Macbeth AH, Pagani JH, Scott Young lii W. Oxytocin: the great facilitator of life. Prog Neurobiol 2009;88:127-51.

11. Stein DJ, Vythilingum B. Love and attachment: the psychobiology of social bonding. CNS Spectrums 2009;14:239-42.

12. Zik JB, Roberts DL. The many faces of oxytocin: implications for psychiatry. Psychiatry Res 2015;226:31-7.

13. Williams PD, Bock MG, Evans BE, Freidinger RM, Pettibone DJ. Progress in the development of oxytocin antagonists for use in preterm labor. Adv Exp Med Biol 1998;449:473-9.

14. Jankowski M, Broderick TL, Gutkowska J. Oxytocin and cardioprotection in diabetes and obesity. BMC Endocr Disord 2016;16:34.

15. Colaianni G, Sun L, Zaidi M, Zallone A. Oxytocin and bone. Am J Physiol Regul Integr Comp Physiol 2014;307:R970-7.

16. Zagoory-Sharon O, Schroeder M, Levine A, Moran TH, Weller A. Adaptation to lactation in OLETF rats lacking CCK-1 receptors: body weight, fat tissues, leptin and oxytocin. Int J Obes (Lond) 2008;32:1211-21.

17. Blevins JE, Schwartz MW, Baskin DG. Evidence that paraventricular nucleus oxytocin neurons link hypothalamic leptin action to caudal brain stem nuclei controlling meal size. Am J Physiol Regul Integr Comp Physiol 2004;287:R87-96.

18. Kimura T, Tanizawa O, Mori K, Brownstein MJ, Okayama H. Structure and expression of a human oxytocin receptor. Nature 1992;356:526-9.

19. Sanborn BM, Dodge K, Monga M, Qian A, Wang W, Yue C. Molecular mechanisms regulating the effects of oxytocin on myometrial intracellular calcium. Adv Exp Med Biol 1998;449:277-86.

20. Akerlund M, Bossmar T, Brouard R, Kostrzewska A, Laudanski T, Lemancewicz A, Serradeil-Le Gal C, Steinwall M. Receptor binding of oxytocin and vasopressin antagonists and inhibitory effects on isolated myometrium from preterm and term pregnant women. Br J Obstet Gynaecol 1999;106:1047-53.

21. Sun L, Tamma R, Yuen T, Colaianni G, Ji Y, Cuscito C, Bailey J, Dhawan S, Lu P, Calvano CD, Zhu LL, Zambonin CG, Di Benedetto A, Stachnik A, Liu P, Grano M, Colucci S, Davies TF, New MI, Zallone A, Zaidi M. Functions of vasopressin and oxytocin in bone mass regulation. Proc Natl Acad Sci USA 2016;113:164-9.

22. Poulain DA, Wakerley JB. Electrophysiology of hypothalamic magnocellular neurones secreting oxytocin and vasopressin. Neuroscience 1982;7:773-808.

23. Nishimori K, Young LJ, Guo Q, Wang Z, Insel TR, Matzuk MM. Oxytocin is required for nursing but is not essential for parturition or reproductive behavior. Proc Natl Acad Sci USA 1996;93:11699-704.

24. Legros JJ, Chiodera P, Geenen V, Smitz S, von Frenckell R. Dose-response relationship between plasma oxytocin and cortisol and adrenocorticotropin concentrations during oxytocin infusion in normal men. J Clin Endocrinol Metab 1984;58:105-9. 
25. Chiodera P, Salvarani C, Bacchi-Modena A, Spallanzani R, Cigarini C, Alboni A, Gardini E, Coiro V. Relationship between plasma profiles of oxytocin and adrenocorticotropic hormone during suckling or breast stimulation in women. Horm Res 1991;35:119-23.

26. Yang J. Intrathecal administration of oxytocin induces analgesia in low back pain involving the endogenous opiate peptide system. Spine (Phila Pa 1976) 1994;19:867-71.

27. Murphy MR, Checkley SA, Seckl JR, Lightman SL. Naloxone inhibits oxytocin release at orgasm in man. J Clin Endocrinol Metab 1990;71:1056-8.

28. Pedersen CA, Boccia ML. Oxytocin maintains as well as initiates female sexual behavior: effects of a highly selective oxytocin antagonist. Horm Behav 2002;41:170-7.

29. McCarthy MM. Estrogen modulation of oxytocin and its relation to behavior. Adv Exp Med Biol 1995;395:235-45.

30. Churchland PS, Winkielman P. Modulating social behavior with oxytocin: how does it work? What does it mean? Horm Behav 2012;61:392-9.

31. Kosfeld M, Heinrichs M, Zak PJ, Fischbacher U, Fehr E. Oxytocin increases trust in humans. Nature 2005;435:673-6.

32. De Dreu CK, Greer LL, Handgraaf MJ, Shalvi S, Van Kleef GA, Baas M, Ten Velden FS, Van Dijk E, Feith SW. The neuropeptide oxytocin regulates parochial altruism in intergroup conflict among humans. Science 2010;328:1408-11.

33. Furuya K, Mizumoto Y, Makimura N, Mitsui C, Murakami M, Tokuoka S, Ishikawa N, Imaizumi E, Katayama E, Seki K, Nagata I, Ivell R. Gene expressions of oxytocin and oxytocin receptor in cumulus cells of human ovary. Horm Res 1995;44(Suppl 2):47-9.

34. Frayne J, Nicholson HD. Localization of oxytocin receptors in the human and macaque monkey male reproductive tracts: evidence for a physiological role of oxytocin in the male. Mol Hum Reprod 1998;4:527-32.

35. Nicholson HD, Jenkin L. Oxytocin and prostatic function. Adv Exp Med Biol 1995;395:529-38.

36. Conrad KP, Gellai M, North WG, Valtin H. Influence of oxytocin on renal hemodynamics and sodium excretion. Ann N Y Acad Sci 1993;689:346-62.

37. Gutkowska J, Jankowski M, Lambert C, Mukaddam-Daher S, Zingg HH, McCann SM. Oxytocin releases atrial natriuretic peptide by combining with oxytocin receptors in the heart. Proc Natl Acad Sci USA 1997;94:11704-9.

38. Colaianni G, Di Benedetto A, Zhu LL, Tamma R, Li J, Greco G, Peng Y, Dell'Endice S, Zhu G, Cuscito C, Grano M, Colucci S, Iqbal J, Yuen T, Sun L, Zaidi M, Zallone A. Regulated production of the pituitary hormone oxytocin from murine and human osteoblasts. Biochem Biophys Res Commun 2011;411:512-5.

39. Demontiero O, Vidal C, Duque G. Aging and bone loss: new insights for the clinician. Ther Adv Musculoskelet Dis 2012;4:61-76.

40. Zhao LJ, Jiang H, Papasian CJ, Maulik D, Drees B, Hamilton J, Deng HW. Correlation of obesity and osteoporosis: effect of fat mass on the determination of osteoporosis. J Bone Miner Res 2008;23:17-29.

41. Reid IR. Relationships between fat and bone. Osteoporos Int 2008;19:595-606.

42. Shapses SA, Riedt CS. Bone, body weight, and weight reduction: what are the concerns? J Nutr 2006;136:1453-6.

43. Rosen CJ, Bouxsein ML. Mechanisms of disease: is osteoporosis the obesity of bone? Nat Clin Pract Rheumatol 2006;2:35-43.
44. Li J, Papadopoulos V, Vihma V. Steroid biosynthesis in adipose tissue. Steroids 2015;103:89-104.

45. Lee NK, Karsenty G. Reciprocal regulation of bone and energy metabolism. J Musculoskelet Neuronal Interact 2008;8:351.

46. Yadav VK, Ryu JH, Suda N, Tanaka KF, Gingrich JA, Schutz G, Glorieux FH, Chiang CY, Zajac JD, Insogna KL, Mann JJ, Hen R, Ducy P, Karsenty G. Lrp5 controls bone formation by inhibiting serotonin synthesis in the duodenum. Cell 2008;135:825-37.

47. Ferron M, Hinoi E, Karsenty G, Ducy P. Osteocalcin differentially regulates beta cell and adipocyte gene expression and affects the development of metabolic diseases in wild-type mice. Proc Natl Acad Sci USA 2008;105:5266-70.

48. Raisz LG, Rodan GA. Pathogenesis of osteoporosis. Endocrinol Metab Clin North Am 2003;32:15-24.

49. Karsenty G, Wagner EF. Reaching a genetic and molecular understanding of skeletal development. Dev Cell 2002;2: 389-406.

50. Seeman E, Delmas PD. Bone quality-the material and structural basis of bone strength and fragility. N Engl J Med 2006;354:2250-61.

51. Rodan GA, Martin TJ. Therapeutic approaches to bone diseases. Science 2000;289:1508-14.

52. Teitelbaum SL. Bone resorption by osteoclasts. Science 2000;289:1504-8.

53. Morris E, Currie H. Obesity in menopausal women: more than you might think. Menopause Int 2010;16:97.

54. Kanaley JA, Sames C, Swisher L, Swick AG, Ploutz-Snyder LL, Steppan CM, Sagendorf KS, Feiglin D, Jaynes EB, Meyer RA, Weinstock RS. Abdominal fat distribution in pre- and postmenopausal women: the impact of physical activity, age, and menopausal status. Metabolism 2001;50:976-82.

55. Tchernof A, Desmeules A, Richard C, Laberge P, Daris M, Mailloux J, Rheaume C, Dupont P. Ovarian hormone status and abdominal visceral adipose tissue metabolism. J Clin Endocrinol Metab 2004;89:3425-30.

56. Migliaccio S, Greco EA, Fornari R, Donini LM, Lenzi A. Is obesity in women protective against osteoporosis? Diabetes Metab Syndr Obes 2011;4:273-82.

57. Zhao LJ, Liu YJ, Liu PY, Hamilton J, Recker RR, Deng HW. Relationship of obesity with osteoporosis. J Clin Endocrinol Metab 2007;92:1640-6.

58. Sheu Y, Cauley JA. The role of bone marrow and visceral fat on bone metabolism. Curr Osteoporos Rep 2011;9:67-75.

59. Bredella MA, Torriani M, Ghomi RH, Thomas BJ, Brick DJ, Gerweck AV, Harrington LM, Breggia A, Rosen CJ, Miller KK. Determinants of bone mineral density in obese premenopausal women. Bone 2011;48:748-54.

60. Bredella MA, Torriani M, Ghomi RH, Thomas BJ, Brick DJ, Gerweck AV, Rosen CJ, Klibanski A, Miller KK. Vertebral bone marrow fat is positively associated with visceral fat and inversely associated with IGF-1 in obese women. Obesity (Silver Spring) 2011;19:49-53.

61. Compston JE, Watts NB, Chapurlat R, Cooper C, Boonen S, Greenspan S, Pfeilschifter J, Silverman S, Diez-Perez A, Lindsay R, Saag KG, Netelenbos JC, Gehlbach S, Hooven FH, Flahive J, Adachi JD, Rossini M, Lacroix AZ, Roux C, Sambrook PN, Siris ES. Obesity is not protective against fracture in postmenopausal women: GLOW. Am J Med 2011;124:1043-50.

62. Blouin S, Libouban H, Moreau MF, Chappard D. Orchidectomy models of osteoporosis. Methods Mol Biol 2008;455: 125-34. 
63. Katznelson L. Therapeutic role of androgens in the treatment of osteoporosis in men. Baillieres Clin Endocrinol Metab 1998;12:453-70.

64. Karsenty G, Ferron M, The contribution of bone to whole-organism physiology. Nature 2012;481:314-20.

65. Lee NK, Sowa H, Hinoi E, Ferron M, Ahn JD, Confavreux C, Dacquin R, Mee PJ, McKee MD, Jung DY, Zhang Z, Kim JK, Mauvais-Jarvis F, Ducy P, Karsenty G. Endocrine regulation of energy metabolism by the skeleton. Cell 2007;130:456-69.

66. Holloway WR, Collier FM, Aitken CJ, Myers DE, Hodge JM, Malakellis M, Gough TJ, Collier GR, Nicholson GC. Leptin inhibits osteoclast generation. J Bone Miner Res 2002;17:200-9.

67. Oshima K, Nampei A, Matsuda M, Iwaki M, Fukuhara A, Hashimoto J, Yoshikawa H, Shimomura I. Adiponectin increases bone mass by suppressing osteoclast and activating osteoblast. Biochem Biophys Res Commun 2005;331:520-6.

68. Reid IR. Fat and bone. Arch Biochem Biophys 2010;503:20-7.

69. Ahdjoudj S, Fromigue O, Marie PJ. Plasticity and regulation of human bone marrow stromal osteoprogenitor cells: potential implication in the treatment of age-related bone loss. Histol Histopathol 2004;19:151-7.

70. Deblon N, Veyrat-Durebex C, Bourgoin L, Caillon A, Bussier AL, Petrosino S, Piscitelli F, Legros JJ, Geenen V, Foti M, Wahli W, Di Marzo V, Rohner-Jeanrenaud F. Mechanisms of the antiobesity effects of oxytocin in diet-induced obese rats. PLoS One 2011;6:e25565.

71. Camerino C. Low sympathetic tone and obese phenotype in oxytocin-deficient mice. Obesity (Silver Spring) 2009;17: 980-4.

72. Takayanagi Y, Kasahara Y, Onaka T, Takahashi N, Kawada T, Nishimori K. Oxytocin receptor-deficient mice developed lateonset obesity. Neuroreport 2008;19:951-5.

73. Petersson M, Lagumdzija A, Stark A, Bucht E. Oxytocin stimulates proliferation of human osteoblast-like cells. Peptides 2002;23:1121-6.

74. Wilson EJ, Hollenberg MD. Effects of oxytocin and vasopressin on the preadipocyte 3T3-F442A cell line. Biochem Cell Biol 1987;65:211-8.

75. Scheideler M, Elabd C, Zaragosi LE, Chiellini C, Hackl H, Sanchez-Cabo F, Yadav S, Duszka K, Friedl G, Papak C, Prokesch A, Windhager R, Ailhaud G, Dani C, Amri EZ, Trajanoski Z. Comparative transcriptomics of human multipotent stem cells during adipogenesis and osteoblastogenesis. BMC Genomics 2008;9:340.

76. Copland JA, Ives KL, Simmons DJ, Soloff MS. Functional oxytocin receptors discovered in human osteoblasts. Endocrinology 1999;140:4371-4.

77. Blackmore PF, Augert G. Effect of hormones on cytosolic free calcium in adipocytes. Cell Calcium 1989;10:561-7.

78. Lee HM, Fain JN. Regulation of oxytocin-induced phosphoinositide breakdown in adipocytes by adenosine, isoproterenol and insulin. Biochim Biophys Acta 1989;1013:73-9.

79. Barradas AM, Fernandes HA, Groen N, Chai YC, Schrooten J, van de Peppel J, van Leeuwen JP, van Blitterswijk CA, de Boer J. A calcium-induced signaling cascade leading to osteogenic differentiation of human bone marrow-derived mesenchymal stromal cells. Biomaterials 2012;33:3205-15.

80. Floyd ZE, Stephens JM. Interferon-gamma-mediated activation and ubiquitin-proteasome-dependent degradation of PPARgamma in adipocytes. J Biol Chem 2002;277:4062-8.
81. Jabbour HN, Sales KJ, Boddy SC, Anderson RA, Williams AR. A positive feedback loop that regulates cyclooxygenase-2 expression and prostaglandin F2alpha synthesis via the F-seriesprostanoid receptor and extracellular signal-regulated kinase 1/2 signaling pathway. Endocrinology 2005;146:4657-64.

82. Di Benedetto A, Sun L, Zambonin CG, Tamma R, Nico B, Calvano CD, Colaianni G, Ji Y, Mori G, Grano M, Lu P, Colucci S, Yuen T, New MI, Zallone A, Zaidi M. Osteoblast regulation via ligandactivated nuclear trafficking of the oxytocin receptor. Proc Natl Acad Sci USA 2014;111:16502-7.

83. Zhuang LN, Hu WX, Xin SM, Zhao J, Pei G. Beta-arrestin-1 protein represses adipogenesis and inflammatory responses through its interaction with peroxisome proliferator-activated receptorgamma (PPARgamma). J Biol Chem 2011;286:28403-13.

84. Augoulea A, Mastorakos G, Lambrinoudaki I, Christodoulakos G, Creatsas G. Role of postmenopausal hormone replacement therapy on body fat gain and leptin levels. Gynecol Endocrinol 2005;20:227-35.

85. Hassager C, Christiansen C. Estrogen/gestagen therapy changes soft tissue body composition in postmenopausal women. Metabolism 1989;38:662-65.

86. Wing RR, Matthews KA, Kuller LH, Meilahn EN, Plantinga PL. Weight gain at the time of menopause. Arch Intern Med 1991;151:97-102.

87. Garaulet M, Perez-Llamas F, Baraza JC, Garcia-Prieto MD, Fardy PS, Tebar FJ, Zamora S. Body fat distribution in pre-and postmenopausal women: metabolic and anthropometric variables. J Nutr Health Aging 2002;6:123-6.

88. Mendelsohn ME, Karas RH. Molecular and cellular basis of cardiovascular gender differences. Science 2005;308: 1583-7.

89. Andersson N, Islander U, Egecioglu E, Lof E, Swanson C, Moverare-Skrtic S, Sjogren K, Lindberg MK, Carlsten H, Ohlsson C. Investigation of central versus peripheral effects of estradiol in ovariectomized mice. J Endocrinol 2005;187:303-9.

90. Jensen LB, Vestergaard P, Hermann AP, Gram J, Eiken P, Abrahamsen B, Brot C, Kolthoff N, Sorensen $\mathrm{OH}$, Beck-Nielsen $\mathrm{H}$, Nielsen SP, Charles P, Mosekilde L. Hormone replacement therapy dissociates fat mass and bone mass, and tends to reduce weight gain in early postmenopausal women: a randomized controlled 5-year clinical trial of the Danish Osteoporosis Prevention Study. J Bone Miner Res 2003;18:333-42.

91. Sumino H, Ichikawa S, Yoshida A, Murakami M, Kanda T, Mizunuma H, Sakamaki T, Kurabayashi M. Effects of hormone replacement therapy on weight, abdominal fat distribution, and lipid levels in Japanese postmenopausal women. Int J Obes Relat Metab Disord 2003;27:1044-51.

92. Santen RJ. The oestrogen paradox: a hypothesis. Endokrynol Pol 2007;58:222-7.

93. Vickers MR, MacLennan AH, Lawton B, Ford D, Martin J, Meredith SK, DeStavola BL, Rose S, Dowell A, Wilkes HC, Darbyshire JH, Meade TW. Main morbidities recorded in the women's international study of long duration oestrogen after menopause (WISDOM): a randomised controlled trial of hormone replacement therapy in postmenopausal women. BMJ 2007;335:239.

94. Brettes JP, Mathelin C. [Hormone replacement therapy in postmenopausal women and breast cancer risk: impact of estrogens deprivation and timing hypothesis]. Gynecol Obstet Fertil 2007;35:1092-4. 
95. Alessandri N, Piccioni MG, Isabelli V, Alessandri G, Di Matteo A, Padovani D, Rondoni G, Camardella B, Parlapiano C. Morphological and functional changes of cardiovascular system in postmenopausal women. Eur Rev Med Pharmacol Sci 2007;11:107-17.

96. Kasukawa Y, Miyakoshi N, Srivastava AK, Nozaka K, Maekawa S, Baylink DJ, Mohan S, Itoi E. The selective cyclooxygenase-2 inhibitor celecoxib reduces bone resorption, but not bone formation, in ovariectomized mice in vivo. Tohoku J Exp Med 2007;211:275-83.

97. Mundy G, Garrett R, Harris S, Chan J, Chen D, Rossini G, Boyce B, Zhao M, Gutierrez G. Stimulation of bone formation in vitro and in rodents by statins. Science 1999;286:1946-9.

98. Simic P, Culej JB, Orlic I, Grgurevic L, Draca N, Spaventi R, Vukicevic $S$. Systemically administered bone morphogenetic protein- 6 restores bone in aged ovariectomized rats by increasing bone formation and suppressing bone resorption. J Biol Chem 2006;281:25509-21.

99. Sambrook P, Cooper C. Osteoporosis. Lancet 2006;367: 2010-8.

100. McCormick RK. Osteoporosis: integrating biomarkers and other diagnostic correlates into the management of bone fragility. Altern Med Rev 2007;12:113-45.

101. Rizzoli R, Burlet N, Cahall D, Delmas PD, Eriksen EF, Felsenberg D, Grbic J, Jontell M, Landesberg R, Laslop A, Wollenhaupt M, Papapoulos S, Sezer O, Sprafka M, Reginster JY. Osteonecrosis of the jaw and bisphosphonate treatment for osteoporosis. Bone 2008;42:841-7.

102. Graham DY, Malaty HM. Alendronate gastric ulcers. Aliment Pharmacol Ther 1999;13:515-9.

103. Greenspan SL, Bone HG, Ettinger MP, Hanley DA, Lindsay R, Zanchetta JR, Blosch CM, Mathisen AL, Morris SA, Marriott TB. Effect of recombinant human parathyroid hormone (1-84) on vertebral fracture and bone mineral density in postmenopausal women with osteoporosis: a randomized trial. Ann Intern Med 2007;146:326-39.

104. Ring RH, Malberg JE, Potestio L, Ping J, Boikess S, Luo B, Schechter LE, Rizzo S, Rahman Z, Rosenzweig-Lipson S. Anxiolytic-like activity of oxytocin in male mice: behavioral and autonomic evidence, therapeutic implications. Psychopharmacology (Berl) 2006;185:218-25.

105. Bordicchia M, Liu D, Amri EZ, Ailhaud G, Dessi-Fulgheri P, Zhang C, Takahashi N, Sarzani R, Collins S. Cardiac natriuretic peptides act via 338 MAPK to induce the brown fat thermogenic program in mouse and human adipocytes. J Clin Invest 2012;122:1022-36.

106. Blevins JE, Thompson BW, Anekonda VT, Ho JM, Graham JL, Roberts ZS, Hwang BH, Ogimoto K, Wolden-Hanson TH, Nelson J, Kaiyala KJ, Havel PJ, Bales KL, Morton GJ, Schwartz MW, Baskin DG. Chronic CNS oxytocin signaling preferentially induces fat loss in high fat diet-fed rats by enhancing satiety responses and increasing lipid utilization. Am J Physiol Regul Integr Comp Physiol 2016;310:640-58.

107. Zhang G, Bai H, Zhang H, Dean C, Wu Q, Li J, Guariglia S, Meng $\mathrm{Q}$, Cai D. Neuropeptide exocytosis involving synaptotagmin-4 and oxytocin in hypothalamic programming of body weight and energy balance. Neuron 2011;69:523-35.

108. Morton GJ, Thatcher BS, Reidelberger RD, Ogimoto K, Wolden-Hanson T, Baskin DG, Schwartz MW, Blevins JE.
Peripheral oxytocin suppresses food intake and causes weight loss in diet-induced obese rats. Am J Physiol Endocrinol Metab 2012;302:E134-44.

109. Li B, Jiang Y, Sun J, Liang J, Jin Y. MR spectroscopy for assessing the effects of oxytocin on marrow adipogenesis induced by glucocorticoid in rabbits. Acta Radiol 2016;57:701-7.

110. Beranger GE, Djedaini M, Battaglia S, Roux CH, Scheideler M, Heymann D, Amri EZ, Pisani DF. Oxytocin reverses osteoporosis in a sex-dependent manner. Front Endocrinol (Lausanne) 2015;6:81.

111. Szeto A, McCabe PM, Nation DA, Tabak BA, Rossetti MA, McCullough ME, Schneiderman N. Mendez AJ, Evaluation of enzyme immunoassay and radioimmunoassay methods for the measurement of plasma oxytocin. Psychosom Med 2011;73:393-400.

112. Breuil V, Amri EZ, Panaia-Ferrari P, Testa J, Elabd C, AlbertSabonnadiere C, Roux CH, Ailhaud G, Dani C, Carle GF, EullerZiegler L. Oxytocin and bone remodelling: relationships with neuropituitary hormones, bone status and body composition. Joint Bone Spine 2011;78:611-5.

113. Breuil V, Panaia-Ferrari P, Fontas E, Roux C, Kolta S, Eastell R, Ben Yahia H, Faure S, Gossiel F, Benhamou CL, Euller-Ziegler L, Amri EZ. Oxytocin, a new determinant of bone mineral density in post-menopausal women: analysis of the OPUS cohort. J Clin Endocrinol Metab 2014;99:E634-41.

114. Gajdosechova L, Krskova K, Segarra AB, Spolcova A, Suski M, Olszanecki R, Zorad S. Hypooxytocinaemia in obese Zucker rats relates to oxytocin degradation in liver and adipose tissue. J Endocrinol 2014;220:333-43.

115. Breuil V, Fontas E, Chapurlat R, Panaia-Ferrari P, Yahia HB, Faure S, Euller-Ziegler L, Amri EZ, Szulc P. Oxytocin and bone status in men: analysis of the MINOS cohort. Osteoporos Int 2015;26:2877-82.

116. Chaves VE, Tilelli CQ, Brito NA, Brito MN. Role of oxytocin in energy metabolism. Peptides 2013;45:9-14.

117. Lawson EA, Marengi DA, DeSanti RL, Holmes TM, Schoenfeld DA, Tolley CJ, Oxytocin reduces caloric intake in men. Obesity (Silver Spring) 2015;23:950-6.

118. Qian W, Zhu T, Tang B, Yu S, Hu H, Sun W, Pan R, Wang J, Wang D, Yang L, Mao C, Zhou L, Yuan G. Decreased circulating levels of oxytocin in obesity and newly diagnosed type 2 diabetic patients. J Clin Endocrinol Metab 2014;99:4683-9.

119. Blevins JE, Baskin DG. Translational and therapeutic potential of oxytocin as an anti-obesity strategy: insights from rodents, nonhuman primates and humans. Physiol Behav 2015;152:438-49.

120. Zhang H, Wu C, Chen Q, Chen X, Xu Z, Wu J, Cai D. Treatment of obesity and diabetes using oxytocin or analogs in patients and mouse models. PLoS One 2013;8:e61477.

121. Jin B, Du Y, Zhang F, Zhang K, Wang L, Cui L. Carbetocin for the prevention of postpartum hemorrhage: a systematic review and meta-analysis of randomized controlled trials. J Matern Fetal Neonatal Med 2016;29:400-7.

122. Cavallaro G, Maniscalco L, Campisi M, Schillaci D, Giammona G. Synthesis, characterization and in vitro cytotoxicity studies of a macromolecular conjugate of paclitaxel bearing oxytocin as targeting moiety. Eur J Pharm Biopharm 2007;66:182-92. 